DOI https://doi.org/10.30525/978-9934-26-008-7.1-6

\title{
ОСОБЛИВОСТІ ПРОСКТУВАННЯ ПЕРЕТВОРЮВАЧІВ ЧАСТОТИ ДЛЯ ПІДВОДНИХ АПАРАТІВ
}

\author{
Костенко Д. В., Трибулькевич С. Л.
}

\section{ВСТУП}

Одним із застосувань частотно-регульованого привода $\epsilon$ рушійно-кермовий комплекс ненаселених підводних апаратів. У більшості надводних і підводних судів рушії, як правило, не призначені для маневрування. Маневрування здійснюється рулями, наприклад, підводні човни мають керма як для зміни курсу, так i для маневрування глибиною. Підводні апарати, на відміну від більших судів, маневрують тільки шляхом зміни упорів рушіїв, що вимагає від приводів рушіїв плавного регулювання у всьому діапазоні частот обертання. Сучасні підводні апарати зазвичай оснащуються великою кількістю рушіїв, маневрові й швидкісні апарати мають на борту вісім і більше рушіїв, частина рушіїв відповідає за рух вперед-назад, інша частина - для стабілізації за креном й диферентом. У зв'язку з тим, що до електроустаткування підводних апаратів висуваються дуже тверді вимоги за масогабаритними показниками, температурним режимом, умовами електромагнітної сумісності, довгий час не вдавалося створити систему керування приводом рушія 3 асинхронним двигуном. У минулому широко використовувалися для підводних апаратів двигуни постійного струму й навіть електрогідравлічні установки.

Розвиток мікроконтролерної техніки, поява компактних силових інтелектуальних модулів дозволили спроєктувати малогабаритний перетворювач частоти, який можна застосовувати в складі електроустаткування підводного апарата.

\section{1. Схемотехнічна частина}

Основним силовим елементом перетворювача частоти є інвертор, який містить 6 IGBT транзисторів і спеціалізований підсилювач для 
управління затворами транзисторів - драйвер ${ }^{1}$. Натепер великого поширення набули інтелектуальні силові модулі (IPМ). Ці пристрої поєднують в собі силові транзистори, драйвер, деякі кола захисту. Хоча інтелектуальний модуль коштує дорожче, ніж дискретні транзистори й драйвер, використання модуля має ряд переваг:

- апаратно реалізовані функції захисту (за струмом, температурою, зниженню напруги в колах живлення, від наскрізних струмів і тому подібне);

- менші габарити;

- готова силова частина схеми 3 мінімальними паразитними індуктивностями.

Будемо вважати доцільним застосування інтелектуального модуля. IR випускає лінійку інтелектуальних силових модулів 6-го класу, що забезпечує роботу під час безпосереднього підключення до мережі $220 \mathrm{~B}$, які відрізняються один від одного допустимим струмом від 6 до 30 А, складом захисних функцій, схемотехнічними особливостями. Для потужностей у десятки-сотні Ватт є лінійка модулів у корпусах поверхневого монтажу. Наприклад, модуль IRSM836-045 випускається в корпусі PQFN iз розміром 12 мм, має допустимий вихідний струм 4 А, дозволяє роботу з двигуном близько 130 Ватт без додаткового тепловідводу.

Вибір транзисторів за струмом для роботи в перетворювачі частоти - досить нетривіальне завдання, оскільки в транзисторів нормується допустимий постійний струм, а не вихідний струм інвертора. Слід враховувати такі фактори:

- під час роботи на низьких швидкостях обертання слід враховувати теплову інерційність напівпровідників, у межі розрахунок вести не для наявного значення струму, а для амплітудного;

- транзистори працюють у режимі з модуляцією, тому необхідно враховувати не тільки статичні, а й динамічні втрати;

- можливо непередбачуване збільшення струму двигуна, пов' язане з моментом на валу.

Для спрощення вибору модуля в документації на модулі вказаний діапазон потужностей двигунів і забезпечений значний запас за струмом у транзисторів.

${ }^{1}$ Мікроконтролерне керування електроприводом. Частина $1:$ навчальний посібник / В.С. Блінцов, О.К. Жук, Д.О. Жук, Д.В. Костенко, В.В. Шевченко. Миколаїв : НУК, 2014. 264 с. 
Під час вибору керувального мікроконтролера для перетворювача частоти насамперед треба враховувати питання електромагнітної сумісності й надійності. 3 боку електромагнітної сумісності перетворювач частоти має силовий блок, який $\epsilon$ джерелом сильних індуктивних перешкод, аналоговий вимірювальний блок, який є реципієнтом перешкод, і цифровий керувальний блок, який може як генерувати, так і сприймати перешкоди. Багато питань електромагнітної сумісності можуть бути розв'язані конструктивно й схемотехнічно, але i сам мікроконтролер повинен бути стійким до перешкод. 3 цього боку інтерес представляють мікроконтролери фірми Microchip Technology, які мають високу стійкість до електромагнітних перешкод, випускаються у виконанні з розширеним температурним діапазоном. Щорічно видається так званий reliability report документ, який містить результати випробувань інтенсивності відмов компонентів у важких умовах ${ }^{2}$.

Під час розробки схеми використані рекомендації із заміток із застосування AN-900³ . Схема електрична принципова показана на рис. 1. Пристрій підключається до двох джерел живлення постійного струму: силове 300 В і стабілізоване 15 В для кіл управління.

Розглянемо призначення елементів.

DA5 - інтелектуальний силовий модуль, основний елемент силової схеми. DD1 - мікроконтролер, який реалізує закони управління та захисту.

R1, R2, R6, R7, R8, C6, C7, C8 - додаткові фільтри на аналогових входах мікроконтролера.

R9, C3 - фільтр живлення аналогових модулів мікроконтролера.

VD1, VD2 - світлодіоди індикації режимів «робота» й «аварія».

DA1 - стабілізатор 5 В для живлення мікроконтролера.

DA2 - компаратор, що забезпечує відсічення за струмом.

DA3 - компаратор, що забезпечує апаратний захист від перенапруг.

${ }^{2}$ Мікроконтролерне керування електроприводом. Частина $1:$ навчальний посібник / В.С. Блінцов, О.К. Жук, Д.О. Жук, Д.В. Костенко, В.В. Шевченко. Миколаїв : НУК, 2014. 264 с.

${ }^{3}$ Burroughs Jon. AN900. Controlling 3-Phase AC Induction Motors Using the PIC18F4431. 2004. Microchip Technology Inc. 24 p. URL: http://ww1.microchip.com/downloads/en/appnotes/00900a.pdf. 
DA4 - підсилювач струму.

DA5 - підсилювач напруги.

DA6 - драйвер послідовного інтерфейсу CAN.

C23 ... C28 - бустрепні конденсатори.

Температурний захист інтелектуального модуля забезпечується внутрішніми терморезистором і компаратором. Для вибору порогу спрацьовування слід встановити резистор R17 між виводом модуля та загальним проводом. У технічній документації рекомендована величина цього резистора 6,8 кОм, що відповідає порогу спрацьовування близько 100 градусів. Сигнал із цього резистора подається на аналоговий вхід мікроконтролера, де може додатково відстежуватися температура модуля. Виводи емітерів катодної групи транзисторів не підключені до мінусової шини модуля, а виводяться назовні. Це дає можливість встановити між емітерами й мінусом джерела живлення шунт R24, із падіння напруги на якому можна оцінювати режим роботи перетворювача.

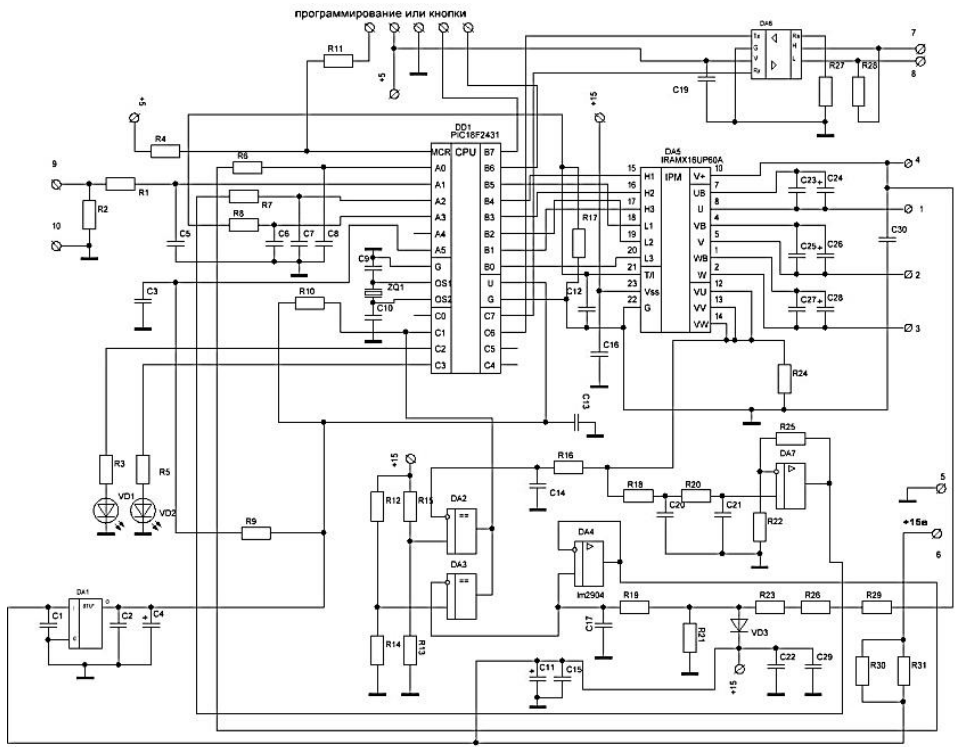

Рис. 1. Перетворювач частоти. Схема електрична принципова

Напруга із шунта R24 подається на компаратор DA2, із виходу якого сигнал подається на вхід апаратного захисту мікроконтролера. 
У разі спрацьовування компаратора всі транзистори модуля будуть переведені в неактивний стан. Транзистори модуля витримують металеве коротке замикання в разі напруги 300 В протягом 10 мкс, зазначене коло повинно забезпечити спрацьовування відсічення за менший час. Крім того, сигнал із шунта передається в підсилювач DA7, із виходу якого посилена напруга подається на аналоговий вхід мікроконтролера. Підсилювач поєднує в собі функції фільтра, що забезпечує придушення пульсацій на частоті несучої. Аналогічно організований захист за напругою. Сигнал із високовольтного дільника подається на підсилювач і на компаратор. Вихід компаратора об'єднаний із виходом токового компаратора за принципом «монтажне I», а вихід підсилювача подається на один 3 аналогових входів мікроконтролера.

Під час розрахунків параметрів елементів схеми, окрім заміток по застосуванню, використовується традиційна схемотехнічна література ${ }^{4}$.

Активні компоненти, що використовуються в схемі, підключені за типовими схемами, тому параметри пасивних компонентів, не показаних у розрахунках, відповідають рекомендованим. Місткості бустрепних конденсаторів вибираються за графіком у довідкових даних інтелектуального модуля. Для частоти несучої 10 кГц місткість повинна скласти 4,7 мкФ.

Вимірювальний резистор R24 повинен бути не низькоомним і не мати індуктивності. Натепер доступні низькоомні резистори.

Для поверхневого монтажу типорозміру 2512 з розсіюваною потужністю 1 Вт вибираємо R24 = 0,01 Ом. Задаємося часом завершення перехідного процесу 1 мкс. Тоді постійна часу кола R16C14 повинна ставити:

$$
\begin{aligned}
\tau & =\mathrm{t} / 4,6 \\
\tau & =\mathrm{t} / 4,6 .
\end{aligned}
$$

Обираємо $\mathrm{C} 14=30$ пФ. Тоді:

$$
\mathrm{R} 16=\mathrm{t} /(4,6 \cdot \mathrm{C} 14)=1 \cdot 10^{-6} /\left(4,6 \cdot 30 \cdot 10^{-12}\right) \approx 7200 .
$$

Обираємо R16 $=7,5$ кОм.

При струмі 30 А напруга на шунт складе $\mathrm{U}=\mathrm{I} \cdot \mathrm{R} 24=30 \cdot 0,01=0,3$. Таку ж напругу повинен формувати дільник R15R13, тому що напруга на дільнику становить 15 B, отже

4 Титце У., Шенк К. Полупроводниковая схемотехника : справочное руководство / пер. с нем. Москва : Мир, 1982. 512 с.: ил. 
коефіцієнт розподілу повинен бути 1:50. Вибираємо R13 = 1 кОм. Тоді $\mathrm{R} 15=49 \cdot \mathrm{R} 13=49 \cdot 1000=49000$. Вибираємо 3 відхиленням в безпечну сторону R15 = 51 кОм. Під час вибору елементів високовольтного дільника слід враховувати, що резистори типорозміру 0805 мають допустиму напругу 250 В, тому високовольтний резистор повинен складатися 3 мінімум двох послідовно з'єднаних резисторів типорозміру 0805. Вибираємо із запасом три резистори, R23 = R26 = R29 = 1 МОм. Вибираємо коефіцієнт ділення 1:100. Тоді

$$
\mathrm{R} 21=(\mathrm{R} 23+\mathrm{R} 26+\mathrm{R} 29) / 99 \approx 30 \mathrm{KOM} .
$$

Захисний діод VD3 вибираємо типу 114148. Фільтр R19C17 забезпечує придушення перешкод на частоті несучої, вибираємо його частоту зрізу 300 Гц, задаємося $\mathrm{C} 17=10$ нФ. Тоді:

$\mathrm{R} 19=1 /(2 \pi \cdot \mathrm{C} 17 \cdot \mathrm{f})=1 /\left(2 \cdot 3,14 \cdot 10 \cdot 10^{-9} \cdot 300\right)=53079 \approx 51 \kappa \mathrm{м}$.

Максимально допустима напруга модуля становить $600 \mathrm{~B}$, високовольтні електролітичні конденсатори поширених серій мають максимальну напругу 450 В. Вибираємо поріг спрацьовування апаратного захисту за напругою 450 В. На виході дільника водночас напруга складе 4,5 В. Вибираємо опір резистора R14 = 30 кОм. Тоді:

$$
\mathrm{R} 12=\frac{\mathrm{U}_{\text {вх }}-\mathrm{U}_{\text {вых }}}{\mathrm{I}_{\text {д }}}=\frac{\left(\mathrm{U}_{\text {вх }}-\mathrm{U}_{\text {вых }}\right)}{\mathrm{U}_{\text {вых }}} \mathrm{R} 14=\frac{15-4,5}{4,5} 30000=70000 \approx 68 \mathrm{KOM} .
$$

Вибір параметрів струмового підсилювача. 3 урахуванням вихідної потужності 1 кВт визначимо номінальний струм в шині постійного струму:

$$
\mathrm{I}_{\mathrm{d}}=\mathrm{P} / \mathrm{U}_{\mathrm{d}}=1000 / 220 \sqrt{2} \approx 3,2 \mathrm{~A} .
$$

Діапазон аналого-цифрового перетворювача мікроконтролера становить 5 В, вибираємо коефіцієнт підсилення 20, що дає можливість вимірювати струми в діапазоні до 25 А, тобто практично до спрацьовування відсічення. Сигнал на шунт має явно виражену пульсацію на частоті несучої, порівняну за амплітудою 3 корисним сигналом. Цю пульсацію необхідно придушити, тому підсилювач повинен мати характеристику фільтра. Будемо вважати допустимим коефіцієнт ослаблення - 40 дБ, вибираємо частоту зрізу фільтра 1 кГц і порядок фільтра 2. Вибираємо фільтр із критичним загасанням. Такий фільтр має дуже гладку амплітудно-частотну характеристику, але легко реалізується на одному ОУ з високим коефіцієнтом посилення. Вибираємо $\mathrm{C} 20=\mathrm{C} 21=0,01$ мкФ, тоді:

$$
\mathrm{R} 18=\mathrm{R} 20=1 /(2 \pi \cdot \mathrm{C} 20 \cdot \mathrm{f})=1 /\left(2 \pi \cdot 0,01 \cdot 10^{-6} \cdot 1000\right) \approx 16 \mathrm{KOM} .
$$


Для отримання коефіцієнта посилення 20 співвідношення опорів R25 i R22 повинно складати 19, водночас для придушення похибки, викликаної вхідними струмами ОУ, повинна виконуватися умова $\mathrm{R} 18+\mathrm{R} 20=\mathrm{R} 25 \mathrm{R} 22$ / (R25 + R22). Зазначена умова виконується при $\mathrm{R} 22=33$ кОм R25 =19R22 =19.33 $\approx 620$ кОм .

Під час вибору опорів резисторів R3 i R4 слід вибрати світлодіоди й задатися прямим струмом. Вибираємо червоний світлодіод L-C170SRCT, зелений L-C170KGCT, задаємося прямим струмом 5 мА, що відповідає яскравості $7 \ldots 8$ МКД. За такого струму отримуємо за графіками в довідкових даних пряму напругу на переході червоного світлодіода 1,7 В, зеленого - 1,9 В. Тоді опору резисторів складуть:

$$
\begin{gathered}
\mathrm{R}=\left(\mathrm{U}_{\text {пит }}-\mathrm{U}_{\text {пр }}\right) / \mathrm{I}_{\text {пр }} ; \\
\mathrm{R}_{\text {кр }}=(5-1,7) / 5 \cdot 10^{-3}=660 ; \\
\mathrm{R}_{\text {зел }}=(5-1,9) / 5 \cdot 10^{-3}=620 .
\end{gathered}
$$

3 боку уніфікації вибираємо однаковими 3 відхиленням у безпечну сторону $\mathrm{R}_{\text {кр }}=\mathrm{R}_{\text {зел }}=6800$ М .

Плата управління конструктивно буде встановлена в безпосередній близькості 3 модулем і піддаватися дії високої температури. Розрахункова температура спрацьовування температурного захисту 100 градусів. Вибираємо компаратори й операційні підсилювачі з допустимою температурою 105 градусів. Компаратори - LM2903, операційні підсилювачі - LM2904. Підтягаючий резистор компаратора $\mathrm{R} 10=5,1$ кОм відповідно до типової схеми включення. Для організації послідовного інтерфейсу вибираємо CAN трансивер МСР2551. Залежно від технічного завдання можуть застосовуватися й інші пристрої, наприклад, трансивери послідовних інтерфейсів RS323 або RS485.

Джерела живлення повинні забезпечувати напруги 5 В для цифрової частини й 15 В для аналогової частини й кіл управління модуля. Вибираємо варіант із живленням від джерела $15 \mathrm{~B}$ із додатковим 5-ти вольтним стабілізатором 78х05. Визначимо струм споживання колами 5 і 15 В, який складається зі споживаного струму активних компонентів, струму дільників та інших пасивних кіл, струмів навантажень активних компонентів.

Розрахунок споживання по колах живлення $5 \mathrm{~B}$ :

$$
\mathrm{I}_{5}=\mathrm{I}_{\mathrm{DD} 1}+2 \mathrm{I}_{\mathrm{VD}}+\mathrm{I}_{\mathrm{R} 10}+\mathrm{I}_{\mathrm{DA} 6},
$$


де $\mathrm{I}_{\mathrm{DD1}}=15 \mathrm{MA} \quad-$ споживаний струм мікроконтролера за максимальної температури й максимальної частоти в режимі Primary_Run;

$2 \mathrm{I}_{\mathrm{VD}}=2 \cdot 5=10 \mathrm{MA}-$ струм, споживаний світлодіодами;

$\mathrm{I}_{\mathrm{R} 10}=\mathrm{U} / \mathrm{R} 10=5 / 5100 \approx 1 \mathrm{MA}-$ струм підтягаючого резистора компаратора;

$\mathrm{I}_{\mathrm{DA6}}$ - струм, споживаний трансивером.

Споживаний струм трансивером складає 10 мА в режимі Recessive i 75 мA в режимі Dominant. Розглянемо найгірший випадок, коли мікроконтролер постійно здійснює зв'язок за послідовним інтерфейсом. Припустимо, що він половину часу приймає інформацію та половину часу передає. Припустимо, що в переданій інформації половину складають нулі, а половину одиниці. Тоді можна вважати, що 75 \% часу трансивер знаходиться в стані Recessive, а $25 \%$ - в стані Dominant:

$$
\begin{gathered}
\mathrm{I}_{\mathrm{DA} 6}=0,25 \cdot 75+0,75 \cdot 10 \approx 26 \mathrm{MA} ; \\
\mathrm{I}_{5}=15+10+1+26=52 \mathrm{MA} .
\end{gathered}
$$

За обчисленим током вибираємо інтегральний стабілізатор середньої потужності МC78M05. Розсіяна потужність у стабілізаторі й споживаний струм складуть з урахуванням власного споживаного струму стабілізатора $\mathrm{I}_{\mathrm{Q}}=6 \mathrm{MA}$ :

$$
\begin{gathered}
\mathrm{P}_{5}=\left(\mathrm{U}_{\mathrm{IN} 5}-\mathrm{U}_{\text {OUT5 }}\right) \cdot \mathrm{I}_{5}+\mathrm{U}_{\mathrm{IN} 5} \cdot \mathrm{I}_{\mathrm{Q}} ; \\
\mathrm{P}_{5}=(15-5) \cdot 52 \cdot 10^{-3}+15 \cdot 6 \cdot 10^{-3}=0,61 \mathrm{BT} ; \\
\mathrm{I}_{\mathrm{IN} 5}=\mathrm{I}_{5}+\mathrm{I}_{\mathrm{Q}}=52+6=58 \mathrm{MA} .
\end{gathered}
$$

Розрахунок теплового режиму стабілізатора.

Максимальна температура кристала стабілізатора МС78M05 становить $\mathrm{T}_{\mathrm{OPR}}=150^{\circ} \mathrm{C}$, температуру навколишнього середовища, виходячи з близькості силового модуля, вважаємо $\mathrm{T}_{\mathrm{Aмв}}=100^{\circ} \mathrm{C}$. Тоді необхідний тепловий опір перехід - середа складе:

$$
\mathrm{R}_{\Theta}=\left(\mathrm{T}_{\mathrm{OPR}}-\mathrm{T}_{\mathrm{AMB}}\right) / \mathrm{P}_{5}=(150-100) / 0,61 \approx 82 \mathrm{~K} / \mathrm{BT} .
$$

Тепловий опір перехід - середа вільно розташованого стабілізатора в корпусі D-PAK становить 92 K / Вт, що говорить про необхідність додаткових заходів за теплоотводом. 3 урахуванням півторакратного запасу будемо вважати допустимим тепловий опір 54 К / Вт. Під час встановлення стабілізатора на плату теплоотводом може служити мідний полігон під стабілізатором, 
залежність розмірів полігону від отриманого теплового опору наводиться в довідкових даних. За графіком для обраного теплового опору вибираємо розміри полігону - квадрат зі стороною 15 мм.

Розрахунок споживаного струму за колом $15 \mathrm{~B}$ :

$$
\mathrm{I}_{15}=\mathrm{I}_{\mathrm{IN} 5}+\mathrm{I}_{2903}+\mathrm{I}_{2904}+\mathrm{I}_{\mathrm{DA} 5}+\mathrm{I}_{\mathrm{R} 12 \mathrm{R} 14}+\mathrm{I}_{\mathrm{R} 15 \mathrm{R} 13},
$$

де $\mathrm{I}_{2903}=2,5 \mathrm{MA}$ - споживаний струм компараторів;

$$
\begin{aligned}
& \mathrm{I}_{2904}=2 \mathrm{MA}-\text { споживаний струм ОУ; } \\
& \mathrm{I}_{\mathrm{R} 12 \mathrm{R} 14}=\mathrm{U} /(\mathrm{R} 12+\mathrm{R} 14)=15 /\left(68 \cdot 10^{3}+30 \cdot 10^{3}\right)=0,15 \mathrm{MA}
\end{aligned}
$$

струм дільника;

$$
\mathrm{I}_{\mathrm{R} 15 \mathrm{R} 13}=\mathrm{U} /(\mathrm{R} 15+\mathrm{R} 13)=15 /\left(51 \cdot 10^{3}+1 \cdot 10^{3}\right)=0,29 \mathrm{MA}
$$
струм дільника.

Для розрахунку споживання модуля скористаємося рекомендаціями 3 AN-10445. Ураховуючи наявність шести IGBT комутаторів, втрати управління силовими ключами складуть:

$$
\mathrm{P}_{\mathrm{S}}=6 \cdot \mathrm{Q}_{\mathrm{G}} \cdot \mathrm{U}_{\mathrm{GE}} \cdot \mathrm{f} \text {, }
$$

де $\mathrm{Q}_{\mathrm{G}}=84 \mathrm{HKл} \mathrm{-} \mathrm{заряд,} \mathrm{необхідний} \mathrm{для} \mathrm{одного} \mathrm{циклу}$ включення - виключення IGBT ключа;

$\mathrm{U}_{\mathrm{GE}}=15 \mathrm{~B}$ - амплітуда напруги на затворі емітер (gate emitter volt age);

$\mathrm{f}=10 \mathrm{~K} Г Ц-$ частота широтно-імпульсної модуляції (далі - ШІМ).

$$
\mathrm{P}_{\mathrm{S}}=6 \cdot 84 \cdot 10^{-9} \cdot 16 \cdot 10 \cdot 10^{3}=0,08 \mathrm{BT} \text {. }
$$

Отже, струм складе $\mathrm{I}_{\mathrm{s}}=\mathrm{P}_{\mathrm{s}} / \mathrm{U}=0,08 / 15 \approx 5,3 \mathrm{MA}$, статичний струм споживання модуля $\mathrm{I}_{\mathrm{QCC}}=3,35 \mathrm{MA}$. Тоді

$$
\begin{aligned}
& \mathrm{I}_{\mathrm{DA} 5}=\mathrm{I}_{\mathrm{S}}+\mathrm{I}_{\mathrm{QCC}}=5,3+3,35 \approx 9 \mathrm{MA} . \\
& \mathrm{I}_{15}=58+2,5+2+0,15+0,29+9 \approx 72 \mathrm{MA} \quad \text { i, відповідно, }
\end{aligned}
$$
потужність джерела $15 \mathrm{~B}$ :

$$
\mathrm{P}_{15}=\mathrm{U} \cdot \mathrm{I}_{15}=15 \cdot 72 \cdot 10^{-3}=1,13 \mathrm{BT} \text {. }
$$

Розрахунок силового випрямляча.

Силова напруга живлення 300 В виходить за допомогою мостового випрямляча Ларіонова (рис. 2) з місткісним фільтром.

5 AN-1044. Plug N Drive Application Overview Integrated Power Module for Appliance Motor Drive / P. Wood, M. Battello, N. Keskar, A. Guerra. 2002. International Rectifier rev. 1. 22 p. URL: https://docplayer.net/34500983Application-note-an-1044-reva.html. 


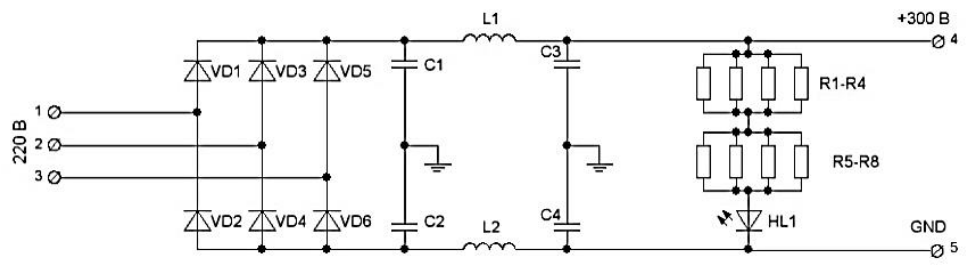

Рис. 2. Силовий випрямляч. Схема електрична принципова

Високочастотний фільтр на виході мосту блокує проходження перешкод, що генеруються на входах інверторів, у лінію зв'язку. Для фільтрації та генерації реактивної потужності використовуються три електролітичні конденсатори, з'єднані в паралель. Коло $з$ резисторів і світлодіоду служить для повільної розрядки конденсаторів у виключеному стані й сигналізує про наявність високої напруги. Поки не згасне цей світлодіод, доторкатися до елементів схеми небезпечно.

Напруга на конденсаторі має пульсуючий характер, амплітуда пульсацій залежить від струму навантаження та місткості конденсатора (рис. 3).

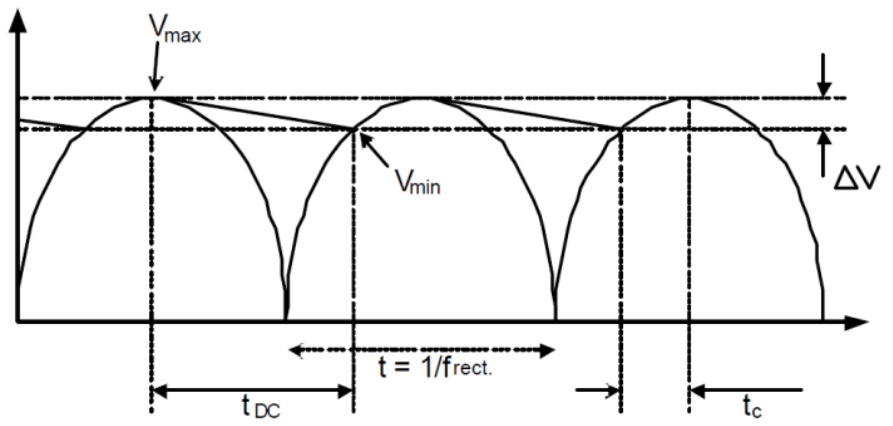

Рис. 3. Форма напруги на конденсаторі фільтра

Вибір місткості можна здійснити за таким виразом:

$$
\mathrm{C}_{\text {min }}=\frac{2 \mathrm{P}_{\mathrm{in}}}{\left(\mathrm{U}_{\max }^{2}-\mathrm{U}_{\min }^{2}\right) \mathrm{f}_{\mathrm{rect}}} .
$$


Задаємося подвоєною амплітудою пульсацій, близькою до $10 \%$ випрямленої напруги, тоді: $\mathrm{U}_{\max }=310 \mathrm{~B}, \mathrm{U}_{\min }=279 \mathrm{~B}$;

$$
\mathrm{C}_{\min }=\frac{2 \cdot 1000}{\left(310^{2}-279^{2}\right) \cdot 100}=0,001 \Phi=1000 \mathrm{MK} \Phi .
$$

Час заряду конденсатора:

$$
\begin{gathered}
\mathrm{t}_{\mathrm{c}}=\frac{\cos ^{-1}\left(\frac{\mathrm{U}_{\text {min }}}{\mathrm{U}_{\max }}\right)}{2 \pi \mathrm{f}_{\text {in }}} ; \\
\mathrm{t}_{\mathrm{c}}=\frac{\cos ^{-1}\left(\frac{279}{310}\right)}{2 \cdot 3,14 \cdot 50}=0,0014 \mathrm{c} .
\end{gathered}
$$

Час розряду конденсатора:

$$
\mathrm{t}_{\mathrm{DC}}=1 / \mathrm{f}_{\text {rect }}-\mathrm{t}_{\mathrm{c}}=1 / 100-0,0014=0,0086 \mathrm{c} .
$$

Середнє значення зарядного струму на інтервалі заряду:

$$
\mathrm{I}_{\text {cpeak }}=\frac{\mathrm{C} \cdot \Delta \mathrm{U}}{\mathrm{t}_{\mathrm{C}}}=\mathrm{C} \frac{\mathrm{U}_{\text {max }}-\mathrm{U}_{\text {min }}}{\mathrm{t}_{\mathrm{C}}}=0,001 \frac{310-279}{0,0014} \approx 22 \mathrm{~A} .
$$

Чинне значення струмів заряду й розряду:

$$
\begin{gathered}
\mathrm{I}_{\text {Crms }}=\sqrt{\mathrm{I}_{\text {Cpeak }}^{2} \mathrm{t}_{\mathrm{c}} \mathrm{f}_{\text {rect }}}=\sqrt{22^{2} \cdot 0,0014 \cdot 100}=8,2 \mathrm{~A} ; \\
\mathrm{I}_{\mathrm{DC \text {Crms }}}=\sqrt{\mathrm{I}_{\text {DCpeak }}^{2} \mathrm{t}_{\mathrm{DC}} \mathrm{f}_{\text {rect }}}=\sqrt{(1000 / 310)^{2} \cdot 0,0086 \cdot 100}=2,99 \mathrm{~A} .
\end{gathered}
$$

Загальне наявне значення струму через конденсатор:

$$
I_{\mathrm{rms}}=\sqrt{I_{\mathrm{DC} \text { rms }}^{2}+\mathrm{I}_{\mathrm{C} \mathrm{rms}}^{2}}=\sqrt{8,2^{2}+2,99^{2}}=8,72 \mathrm{~A} .
$$

Необхідний електролітичний конденсатор не тільки має зазначену місткість, але й допускає обчислений струм пульсацій. Зазначеним умовам задовольняє паралельне з'єднання п'яти конденсаторів типу ELP 220 мкФ, 450 В виробництва HITANO (I = 1,76 A).

Для теплового розрахунку силового модуля слід визначити всі складові частини втрат у модулі - статичні й динамічні втрати в транзисторах і діодах з урахуванням глибини модуляції, коефіцієнта потужності, частоти несучої та інших параметрів. Такий розрахунок досить складний, але в довідкових даних на модуль наводиться сімейство вже розрахованих таких характеристик. За потужності 1 кВт фазний струм складе $\mathrm{I}=\mathrm{P} /(\sqrt{3} \mathrm{U})=1000 /(\sqrt{3} \cdot 220)=2,6 \mathrm{~A}$. Знайдемо відповідне значення втрат $\mathrm{P}_{\text {loss }}=18 \mathrm{BT}$. 
Максимально допустима температура кристалу 150 градусів, задаємося температурою середовища 50 градусів. Задаємося температурою корпусу 100 градусів. У довідкових даних наводяться графіки припустимого фазного струму від температури корпусу. Згідно із цими графіками отримуємо досить великий запас. Розраховуємо тепловий опір радіатор - середа.

Радіатор зручніше не розробляти індивідуально, а виготовити із серійного профілю, наприклад, профіль SK406 (рис. 4) виробництва Fisher Electronics.

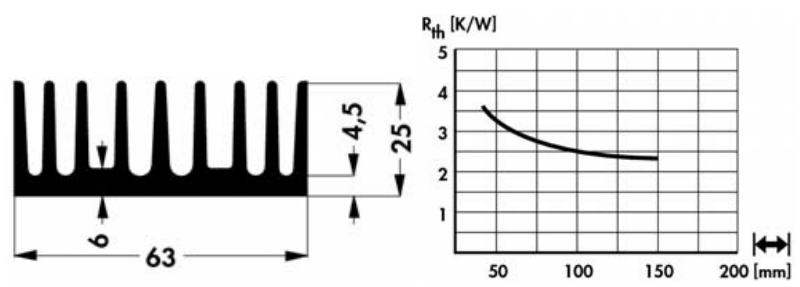

Рис. 4. Радіатор SK406

Профіль має такі розміри (рис. 4), довжина вибирається за графіком, виходячи із заданого теплового опору. Вибираємо довжину радіатора 100 мм.

Перетворювачі частоти (далі - ПЧ) генерують на виході необхідні базові напругу й частоту, використовуючи широтноімпульсну модуляцію. Для класу інверторів 220 В типова базова напруга становить від 0 до $220 \mathrm{~B}$, а базова частота змінюється від 0 до 50 Гц. У вихідному колі інвертора перебувають «перемикаючі» транзистори, що працюють на високій швидкості, створюючи несучу частоту, поверх якої формуються необхідні базові напруга й частота. Несуча частота, або частота перемикання, використовувана для ПЧ на базі IGBT, звичайно становить від 1 до 20 кГц.

Час перемикання - це час, який потрібно IGBT-інвертору на перехід зі стану «виключений» (високий опір) до стану «включений» (низький опір) i навпаки. Для IGBT останнього покоління час перемикання варіюється в діапазоні від 100 до 200 наносекунд (нсек). Оскільки ці пристрої використовуються в колах постійного струму інвертора напругою приблизно 310 В для класу інверторів на $220 \mathrm{~B}$, швидкість зміни напруги в одиницю часу

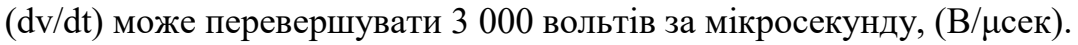


Рекомендується використання Г-образного фільтра $\mathrm{du} / \mathrm{dt}$ для обмеження швидкості наростання на рівні 500 B/мкс. Схема фільтра представлена на рис. 5.

Фільтр du/dt (L-R-C) включається між вихідними клемами ПЧ і руховим кабелем. Крім свого основного призначення - захисту обмоток двигуна від перенапруг, - він дає сильний позитивний ефект на придушення радіоперешкод, тому що, обмежуючи швидкість наростання напруги в руховому кабелі на рівні не більш $500 \mathrm{~B} /$ мкс, обмежує спектр частот коливань у руховому кабелі до 150 кГц. Завдяки цьому обмежуються рівні як індуктивних, так i кондуктивних перешкод у руховому й мережному кабелях. Схема вихідного фільтра представлена на рис. 5.

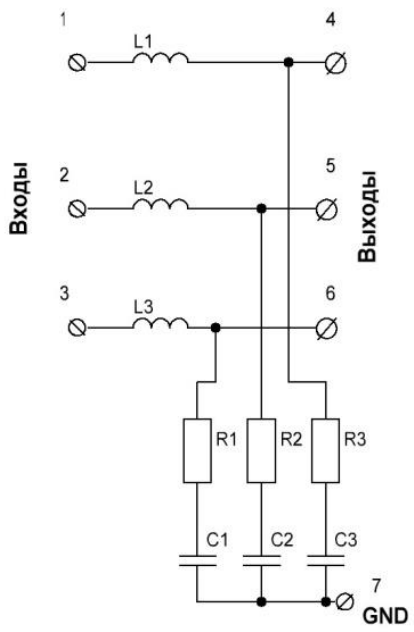

\section{Рис. 5. Схема фільтра}

Параметри фільтра:

$$
\begin{aligned}
& L 1=L 2=L 3=100 \mu \kappa Г н ; \\
& C 1=C 2=C 3=4,7 \mu \Phi ; \\
& R 1=R 2=R 3=150{ }^{\prime} M
\end{aligned}
$$

Передавальна характеристика фільтру наведена на рис. 6 . 


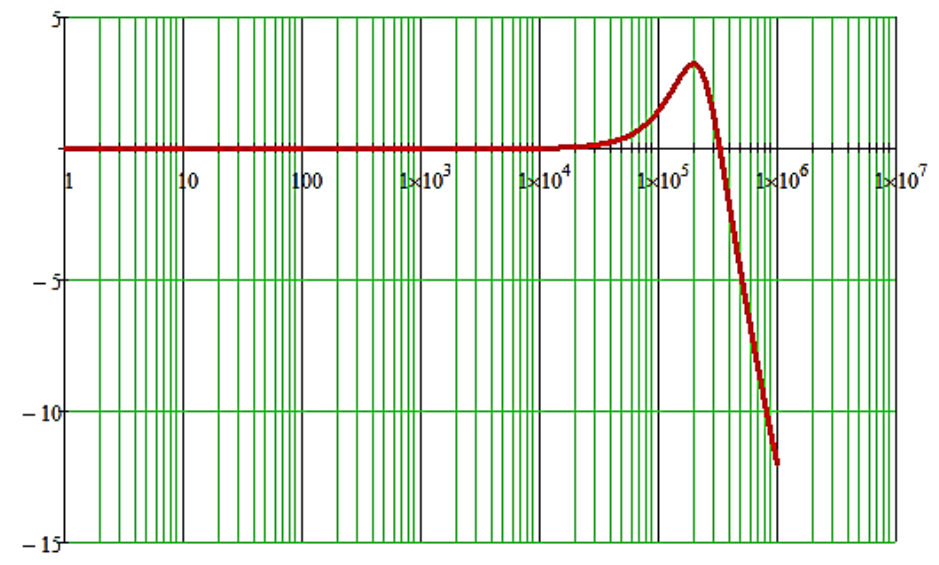

Рис. 6. Передавальна характеристика фільтру

\section{2. Програмне забезпечення}

Програмне забезпечення будується за модульним принципом, розробляється 3 використанням принципу декомпозиції. Обмін параметрами між програмними модулями передбачається робити через таблиці в пам'яті - такий спосіб програє в універсальності, але виграє за швидкодією та простотою дії, - пов'язані безпосередньо 3 управлінням силовим модулем. Розгінгальмування двигуна й таке подібне передбачається робити в процедурах обробки переривань, які будуть викликатися системним таймером або відповідними подіями. Основна програма здійснює управління режимами в самому загальному вигляді й обчислення власне керувального сигналу відповідно до обраного алгоритму управління. Таким чином, основна програма функціонує за принципом кінцевого автомата. Розглянемо його діаграму станів (рис. 7).

У початковому стані ініціалізуються змінні, налаштовуються периферійні модулі мікроконтролера, підготовлюється до включення перетворювач у цілому. Виконується затримка часу для електричних перехідних процесів у силовій схемі. 


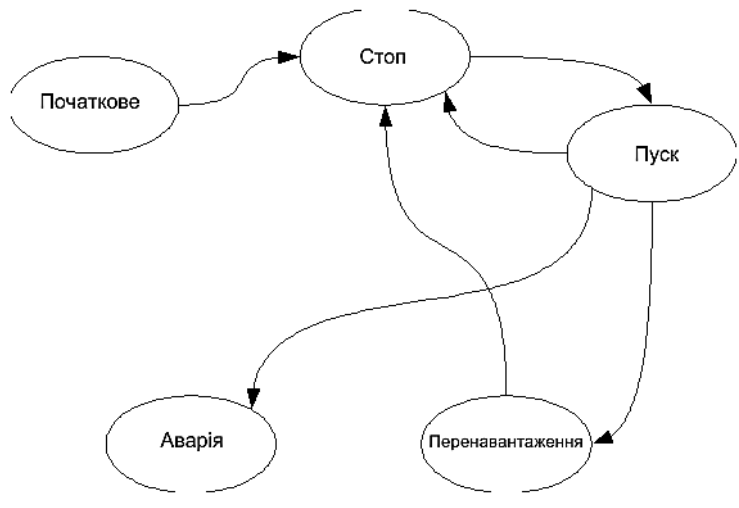

Рис. 7. Діаграма станів перетворювача частоти

У стані «СТОП» програма очікує команду для початку роботи. У стані «ПУСК» формується дозволяючий сигнал для процедури розгону-гальмування, обчислюється керувальний сигнал відповідно до сигналу зворотного зв'язку, аналізуються режими роботи силової схеми на предмет порушень i перевантажень. Стан «ПЕРЕВАНТАЖЕННЯ» аналогічний стану «СТОП», але автомат потрапляє в цей стан не після команди «стоп», а внаслідок порушень у роботі схеми, наприклад, під час перевантаження. Стан «АВАРІЯ» схожий на стан «ПЕРЕВАНТАЖЕННЯ». Відмінність полягає в тому, що зі стану «ПЕРЕВАНТАЖЕННЯ» автомат може перейти в стан «СТОП» і відновити нормальну роботу, а стан «АВАРІЯ» тупиковий, і подальша робота неможлива. Події, що викликають перехід у стани «АВАРІЯ» та «ПЕРЕВАНТАЖЕННЯ», можуть бути уточнені за мірою розвитку програмного забезпечення.

Як уже було сказано, для практичної реалізації обраний мікроконтролер PIC18F2431, що має багатоканальний апаратний ШІМ. Центральними блоками є три модулятори PWM Generator 0, 1 і 2, вихідні сигнали яких через схему логіки подаються на вихідні драйвери. Модулятори можуть працювати в режимі звичайної ШІМ, центрованої ШІМ, одноразового імпульсу. У такому випадку краще застосувати центровану ШІМ, оскільки це знижує генерацію високочастотного шуму силовою схемою. Режими роботи модуляторів управляються регістрами PWMCON0 i PWMCON1. Усі три модулятори працюють синхронно від одного генератора 
несучої. Генератор управляється регістром РTCON. Генератор має свій регістр періоду PTPER, завдяки якому можна отримувати частоти несучої з високою дискретністю та не кратністю частоті основного генератора, але це накладає обмеження на діапазон значень у регістрах тривалості.

Модуль ШІМ володіє дуже важливою додатковою функцією генерацією мертвого часу, що запобігає можливості наскрізних струмів у стійках інвертора. Блок генерації мертвого часу управляється регістром DTCON. Під час використання мертвого часу накладаються обмеження на мінімальну й максимальну тривалість імпульсу ШІМ.

Формування вихідних напруг інвертора виконується методом прямого цифрового синтезу. Для цього в підпрограмі, що викликається системним таймером, визначається поточна фаза. У підпрограмі обробки переривання модуля ШІМ залежно від цієї фази із заздалегідь підготовленої таблиці витягуються значення скважності для всіх трьох каналів ШІМ. Для підвищення швидкодії таблицю краще розмістити в пам'яті даних, тому потрібна процедура, яка перепише значення 3 пам'яті програм у пам'ять даних. Для кращого використання джерела в перетворювачах частоти не використовують ШІМ із синусоїдальною обвідною. Зазвичай застосовують спосіб компенсації третьої гармоніки або спосіб модуляції зображеного вектора. Можна застосувати спосіб, досліджений нами раніше 6 . Розділимо весь діапазон фазного кута на кінцеву кількість секторів, кількість секторів повинна бути кратною 3, вибираємо 96.

Складемо вираз для трьох синусоїд, зміщених на 120 град. 3 областю визначення 0,1 .

$$
\mathrm{A}(\alpha)=\frac{\sin \alpha+1}{2} ; \mathrm{B}(\alpha)=\frac{\sin \left(\alpha+2 \frac{\pi}{3}\right)+1}{2} ; \mathrm{C}(\alpha)=\frac{1+\left(\sin \left(\alpha-2 \frac{\pi}{3}\right)\right.}{2} .
$$

${ }^{6}$ Kostenko D. Phase voltage's forming method for three-phase invertor. Proceedings of the 5th International Conference Unconventional Electromechanical and Electrical Systems, Szczecin and Międzyzdroje, Poland, 5-8 September 2001 : in 3 vol. Szczecin : Institute of Electrical Engineering of the Technical University of Szczecin, 2001. P. 647-650. 
Складемо вираз для корегувальної функції:

$\mathrm{D}(\alpha)=$ if $[(\mathrm{B}(\alpha)<\mathrm{A}(\alpha)) \cdot(\mathrm{B}(\alpha)<\mathrm{C}(\alpha)), \mathrm{B}(\alpha)$, if $[\mathrm{A}(\alpha)$

$<\mathrm{B}(\alpha) \cdot(\mathrm{A}(\alpha)<\mathrm{C}(\alpha)), \mathrm{A}(\alpha), \mathrm{C}(\alpha)]]$

задамо дискретний чac:

$$
\mathrm{i}=0 . .95 ; \mathrm{x}_{\mathrm{i}}=\frac{\pi}{96}+\frac{\pi}{48} \cdot \mathrm{i} ;
$$

формуємо скореговані вихідні сигнали 3 урахуванням поправочного коефіцієнта 0,866 :

$\mathrm{FA}_{\mathrm{i}}=\frac{\mathrm{A}\left(\mathrm{x}_{\mathrm{i}}\right)-\mathrm{D}\left(\mathrm{x}_{\mathrm{i}}\right)}{0.866}, \mathrm{FB}_{\mathrm{i}}=\frac{\mathrm{B}\left(\mathrm{x}_{\mathrm{i}}\right)-\mathrm{D}\left(\mathrm{x}_{\mathrm{i}}\right)}{0.866}, \mathrm{FC}_{\mathrm{i}}=\frac{\mathrm{C}\left(\mathrm{x}_{\mathrm{i}}\right)-\mathrm{D}\left(\mathrm{x}_{\mathrm{i}}\right)}{0.866}$.

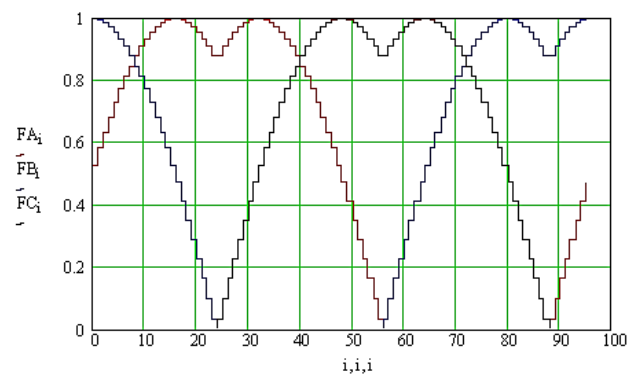

Рис. 8. Розрахунок фазних напруг

Рішенням $є$ таблиці нормалізованих значень для одного каналу: floor $\left[F A_{i} \cdot 256\right]=$

\begin{tabular}{|l|l|l|}
\hline 135 & & \\
\hline 149 & & \\
\hline 162 & & \\
\hline 175 & & \\
\hline 186 & & \\
\hline 197 & & \\
\hline 208 & & \\
\hline 217 & & \\
\hline 225 & & \\
\hline 233 & & \\
\hline 239 & & \\
\hline 244 & & \\
\hline 249 & & \\
\hline 252 & & \\
\hline 254 & & \\
\hline 255 & & \\
\hline
\end{tabular}


Отримані значення розміщуються в пам'яті програм і під час ініціалізації копіюються в пам'ять даних за допомогою такої процедури.

Складемо підпрограму обробки переривання модуля ШІМ. Як вже було сказано, підпрограма за заданою фазою витягує з таблиці три значення та передає їх у регістри періоду. Крім того, виконується масштабування для забезпечення обраного закону залежності напруги від частоти, перевірка на максимальну тривалість, додаткові корекції. Блок-схема алгоритму показана на рис. 9.

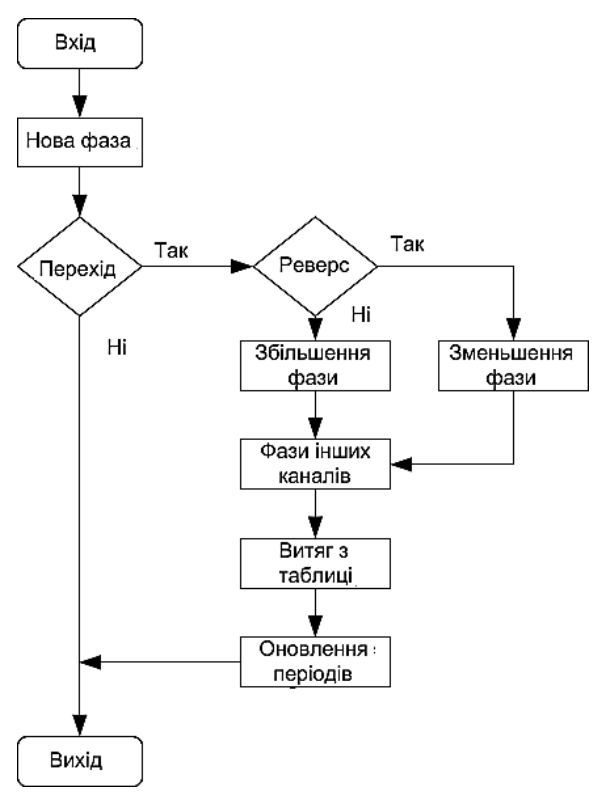

Рис. 9. Блок-схема алгоритму підпрограми обробки переривань ШІМ

У блоці «нова фаза» обчислюється нове значення відповідно до значення миттєвої швидкості FREQ. Далі виконується перевірка переходу в новий сектор. Якщо переходу немає, то оновлень регістрів періоду не вимагається. Якщо перехід $\epsilon$, то визначається, в якому режимі працює пристрій, «вперед» або «назад», що задається прапором DIRECTION. Залежно від напряму номер сектора збільшується або зменшується, визначаються фази для інших двох 
каналів. Витягуються дані, множаться на значення миттєвої напруги VOLT і завантажуються в регістри періоду PDC0, PDC1 і PDC2. Для вилучення даних із таблиці використовується непряма відносна адресація з покажчиком 0.

Використані вихідні дані VOLT i FREQ обчислюються в підпрограмі розгону-гальмування, вхідними параметрами якої $\epsilon$ уставка швидкості й прапор напрямку. Основним обчислюваним параметром є частота, миттєва напруга знаходиться за швидкістю. Відповідно до закону Костенко, щоб забезпечити оптимальний режим роботи АД при всіх значеннях частоти й навантаження, необхідно відносну напругу двигуна змінювати пропорційно добутку відносної частоти на корінь квадратний із відносного моменту ${ }^{7}$. Найпростіша залежність напруги від частоти в разі статичного моменту може бути прямою пропорційністю. Через вплив індуктивної складової частини опору статора водночас пусковий момент буде малий, тому краще реалізувати лінійну залежність із напругою на нульовій частоті $10 \ldots 20 \%$ від номінального. У деяких двигунів може спостерігатися провал моменту на частоті мінімального моменту. Щоб компенсувати цей провал, кращим рішенням буде залежність напруження від частоти у вигляді ламаної лінії з одним зламом (рис. 10).

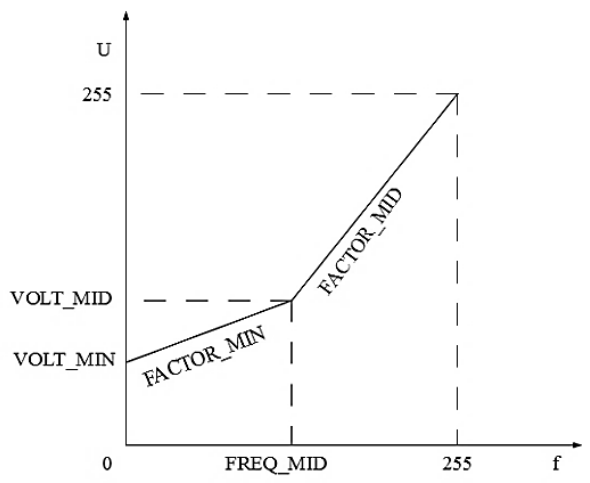

Рис. 10. Залежність напруги від частоти

Точки зламу й нахили ділянок задаються константами під час трансляції програми.

7 Усольцев А.А. Частотное управление асинхронными двигателями : учебное пособие. Санкт-Петербург : СПбГУ ИТМО, 2006. 94 с. 
Власне підпрограма розгону-гальмування отримує уставку частоти FREQ_UST і бітову команду напрямку DIRECTION_UST i здійснює розгін і гальмування 3 урахуванням реверсу шляхом плавного гальмування та наступного розгону в іншу сторону. Додатково виробляються прапори стану, які можуть використовуватися іншими елементами програмного забезпечення: RAZGON_BIT, STATIC_BIT, TORMOZ_BIT, передбачена можливість форсіровки напруги під час розгону, що визначається значенням напруги форсіровки VOLT_FORCE. Швидкості розгону й гальмування задаються незалежно, причому швидкість розгону може складатися 3 двох значень RAZG1 i RAZG2 3 порогом перемикання RAZG_THRESH. Указані величини $є$ змінними й можуть бути змінені в основній програмі.

Блок-схема алгоритму програми представлена на рис. 11.

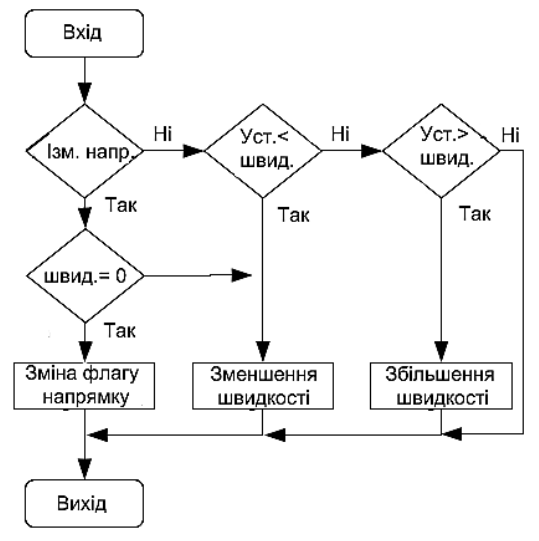

\section{Рис. 11. Блок-схема підпрограми розгону-гальмування}

Програмна реалізація ПІД-регулятора мовою низького рівня $\epsilon$ досить трудомістким завданням, тому виробник мікроконтролерів, компанія Microchip Technology, пропонує ряд готових рішень у вигляді заміток по застосуванню (Application Notes), в тому числі й адаптовану версію для автоматизації електроприводу, наприклад, у складі AN900. Файл PIDInt.asm містить власне програмну реалізацію регулятора. Код оформлений у переміщуваному вигляді, тому може бути легко приєднаний до наявного проєкту за допомогою лінкера. 


\section{ВИСНОВКИ}

Запропоновано апаратно-програмну реалізацію перетворювача частоти 3 ланкою постійного струму для підводного апарату. Така реалізація відрізняється від заводських аналогів меншими малогабаритними показниками, що дуже важливо для підводної робототехніки малого класу, компактним монтажем, який зменшує вплив електромагнітних перешкод, що генеруються перетворювачем частоти, на інформаційно-телекомунікаційну мережу підводного апарату. Програмно-апаратна платформа відрізняється простотою та може бути використана для виготовлення "low cost" лінійки перетворювачів частоти для керування електродвигунами невеликої потужності.

\section{АНОТАЦІЯ}

Самохідні підводні апарати оснащуються великою кількістю рушіїв, які відповідають за рух вперед-назад, рух лагом, повороти й стабілізацію за креном i диферентом. До систем керування електроприводами висуваються дуже жорсткі вимоги за масогабаритними показниками, температурним режимом, умовами електромагнітної сумісності.

Запропоновано апаратно-програмну реалізацію перетворювача частоти з ланкою постійного струму для підводного апарату. Така реалізація відрізняється від заводських аналогів меншими масогабаритними показниками, що дуже важливо для підводної робототехніки малого класу, компактним монтажем, який зменшує вплив електромагнітних перешкод, що генеруються перетворювачем частоти, на інформаційно-телекомунікаційну мережу підводного апарату.

У статті розглянуті способи забезпечення електромагнітної сумісності: високочастотний фільтр на виході випрямляча, який блокує проходження перешкод, що генеруються на входах інверторів, у лінію зв'язку; Г-образний фільтр du/dt для обмеження швидкості наростання напруги на виході інвертора.

Програмно-апаратна платформа відрізняється простотою та може бути використана для виготовлення "low cost" лінійки перетворювачів частоти для керування електродвигунами невеликої потужності.

\section{ЛІТЕРАТУРА}

1. Мікроконтролерне керування електроприводом. Частина 1 : навчальний посібник / В.С. Блінцов, О.К. Жук, Д.О. Жук, Д.В. Костенко, В.В. Шевченко. Миколаїв : НУК, 2014. 264 с. 
2. AN-1044. Plug N Drive Application Overview Integrated Power Module for Appliance Motor Drive / P. Wood, M. Battello, N. Keskar, A. Guerra. 2002. International Rectifier rev. 1.22 p. URL: https://docplayer.net/34500983-Application-note-an-1044-reva.html.

3. Burroughs Jon. AN900. Controlling 3-Phase AC Induction Motors Using the PIC18F4431. 2004. Microchip Technology Inc. 24 p. URL: http://ww1.microchip.com/downloads/en/appnotes/00900a.pdf.

4. Титце У., Шенк К. Полупроводниковая схемотехника : справочное руководство / пер. с нем. Москва : Мир, 1982. 512 с.: ил.

5. Гутников В.С. Интегральная электроника в измерительных устройствах. 2-е изд., перераб. и доп. Ленинград : Энергоатомиздат, Ленингр. отд-ние, 1988. 304 с.: ил.

6. DS39616C PIC18F2331/2431/4331/4431 Data Sheet. 2007. Microchip Technology Inc. 400 p. URL: https://datasheet.octopart.com/ PIC18F2331-I/SO-Microchip-datasheet-5333487.pdf.

7. Усольцев А.А. Частотное управление асинхронными двигателями : учебное пособие. Санкт-Петербург : СПбГУ ИТМО, 2006. 94 c.

8. Kostenko D. Phase voltage's forming method for three-phase invertor. Proceedings of the 5th International Conference Unconventional Electromechanical and Electrical Systems, Szczecin and Międzyzdroje, Poland, 5-8 September 2001 : in 3 vol. Szczecin : Institute of Electrical Engineering of the Technical University of Szczecin, 2001. P. 647-650.

\section{Information about authors:} Kostenko D. V.,

$\mathrm{PhD}$ in Technical Sciences, Associate Professor, Head of the Department of Electrical Engineering of Ship and Robotic Complexes Admiral Makarov National University of Shipbuilding 9, Heroes of Ukraine avenue, Mykolaiv, 54025, Ukraine

Trybulkevich S. L., Senior Lecturer at the Department of Programmable Electronics, Electrical Engineering and Telecommunications Admiral Makarov National University of Shipbuilding 9, Heroes of Ukraine avenue, Mykolaiv, 54025, Ukraine 